\title{
Hubungan Pelanggaran Kontrak Psikologis dan Kepribadian Tipe A dengan Intensi Turnover Karyawan Bank
}

\author{
Ni Putu Ayu Saraswati Ramadhany dan Nicholas Simarmata \\ Program Studi Psikologi, Fakultas Kedokteran, Universitas Udayana \\ saraswatiayu1@gmail.com
}

\begin{abstract}
Abstrak
Salah satu fenomena umum dalam perusahaan adalah gagalnya pemenuhan janji dalam rangka manajemen retensi. Hal tersebut mengarah pada pelanggaran kontrak psikologis karyawan dan memicu intensi turnover. Fenomena lain adalah perbedaan kepribadian karyawan yang berdampak pada hasil kerja, di mana karyawan berkepribadian tipe A memiliki karakteristik yang membuatnya cenderung merespon negatif dan memiliki intensi turnover tinggi. Sejalan dengan hasil survei Watson Wyatt (2007) yang menemukan bahwa tingkat turnover karyawan bank yang mencapai 6,3\%-7,5\% tergolong tinggi dibandingkan industri lainnya, penting untuk meninjau intensi turnover karyawan bank. Berdasarkan uraian tersebut, peneliti ingin mengetahui apakah terdapat hubungan antara pelanggaran kontrak psikologis dan kepribadian tipe A dengan intensi turnover karyawan bank, baik secara simultan maupun individual.

Subyek penelitian adalah 52 orang karyawan bank X Denpasar. Metode penelitian yang digunakan adalah studi korelasi. Pengambilan data dilakukan menggunakan kuesioner. Kuesioner intensi turnover memiliki 23 item sahih dengan koefisien reliabilitas 0,896, kuesioner pelanggaran kontrak psikologis memiliki 18 item sahih dengan koefisien reliabilitas 0,870, dan kuesioner kepribadian tipe A memiliki 35 item sahih dengan koefisien reliabilitas 0,965. Data bersifat normal dan linear. Data penelitian diolah dengan regresi ganda dan korelasi parsial. Hasil penelitian menemukan hubungan positif signifikan antara pelanggaran kontrak psikologis dan kepribadian tipe A dengan intensi turnover, dengan koefisien korelasi $+0,863$. Koefisien determinsi bernilai 0,744 menyatakan bahwa secara simultan, pelanggaran kontrak psikologis dan kepribadian tipe A berkontribusi terhadap intensi turnover sebesar 74,4\%. Kepribadian tipe A memiliki hubungan positif signifikan dengan intensi turnover, dengan koefisien korelasi $+0,556$. Pelanggaran kontrak psikologis tidak memiliki hubungan dengan intensi turnover.
\end{abstract}

Kata kunci: intensi turnover, pelanggaran kontrak psikologis, kepribadian tipe A, karyawan bank

\begin{abstract}
One of the common phenomena in organization is the failure in fulfilling promise in retention management, which leads to psychological contract violation and triggers turnover intention. Other phenomenon is difference of employees personality. Employees with type A personality have characteristics which make them tend to react negatively and have high turnover intention. Analogously with Wattson Wyatt survey (2007) that found turnover level among bank employees reached 6,3\%-7,5\% which was high compared to other industries, it becomes important to study turnover intention among bank employees. According to that, researcher wants to find relationship between psychological contract violation and type A personality on turnover intention of bank employees, simultaneously and individually.

Subjects in this research are 52 employees of bank X in Denpasar. Method used in this research is correlational study. Data are collected by questionnaire. Turnover intention questionnaire has 23 valid items and its reliability coefficient is 0,896 . Psychological contract violation questionnaire has 18 valid items and its reliability coefficient is 0,870 . Type A personality questionnaire has 35 valid items and its reliability coefficient is 0,965 . Data are normal and linear. Multiple regression and partial correlation are run for data analysis. The result of this research finds positive significant relationship between psychological contract violation and type A personality on turnover intention. The reliability coefficient is $+0,863$. The value of coefficient of determination is 0,744 , which shows psychological contract violation and type A personality has $74,4 \%$ contribution to turnover intention. Type A personality has positive significant relationship with turnover intention. The reliability coefficient is 0,556 . There is no relationship between psychological contract violation and turnover intention.
\end{abstract}

Keywords: turnover intention, psychological contract violation, type A personality, bank employees 


\section{LATAR BELAKANG}

Keberadaan karyawan dalam perusahaan sangat penting dalam meningkatkan efektifitas dan efisiensi perusahaan, sehingga perusahaan akan berusaha sebisa mungkin mempertahankan keanggotaan karyawannya dalam perusahaan untuk meningkatkan produktivitas perusahaan dan mencegah timbulnya biaya dari turnover (Oracle, 2012). Literatur manajemen sumber daya manusia menyatakan bahwa manajemen retensi menjadi konsep yang populer untuk mengurangi turnover yang terjadi secara sukarela (Steel, Griffeth, \& Hom, 2002). Turnover sendiri merupakan berhentinya atau penarikan diri karyawan dari tempat kerjanya (Zeffane, dalam Witasari, 2009). Hal ini serupa dengan yang dikemukakan oleh Gómez-Mejía, Balkin, dan Cardy (2010), yang menyatakan bahwa turnover dapat diartikan sebagai ratarata dari karyawan yang meninggalkan perusahaan.

Manajemen retensi merupakan kemampuan untuk mempertahankan karyawan untuk bekerja di perusahaan. Terdapat lima faktor penting yang memengaruhi retensi karyawan, yakni imbalan finansial, peluang pengembangan karir, konten pekerjaan, atmosfer sosial, dan keseimbangan kehidupan pribadi dan pekerjaan (Roehling, Cavanaugh, Moynihan, \& Boswell, dalam De Vos, Meganck, \& Buyens, 2005). Maka dari itu, perusahaan kerap kali menjanjikan pemenuhan aspek manajemen retensi agar karyawan tetap bertahan di perusahaan.

Sayangnya, Stone (1998) menemukan bahwa seringkali seseorang mendapati bahwa janji-janji yang diberikan perusahaan ternyata tidak realistis karena perusahaan tidak memiliki cukup uang dan sumber daya. Karyawan pun kerap kali merasa terkecoh oleh perusahaan. Misalnya dalam hal pemberian gaji, yang mana perusahaan menjanjikan gaji yang memuaskan, padahal dalam kenyataannya gaji yang diterima jauh dari kata memuaskan dan karyawan tak bisa melakukan apa pun terkait hal ini karena sedari awal perusahaan memang tak memberikan batasan jelas mengenai gaji yang memuaskan (Sulasmi, 2012). Hal ini mengarah pada pelanggaran kontrak psikologis.

Kontrak psikologis dipandang sebagai hal yang relevan dalam menjelaskan fenomena yang terjadi dalam perusahaan. Rousseau (dalam Bal, Cooman, \& Mol, 2011) menyatakan bahwa kontrak psikologis merupakan kepercayaan individu terhadap perjanjian pertukaran antara perusahaan tersebut dengan karyawan. Pelanggaran kontrak psikologis terjadi ketika karyawan yang bersangkutan tidak menerima balas jasa yang sesuai dengan yang dijanjikan oleh perusahaan (Zottoli, 2003). Pelanggaran kontrak psikologis terkait dengan efektifitas manajemen retensi karena sementara manajemen retensi merujuk pada imbalan yang diberikan oleh perusahaan dalam rangka mengurangi turnover nyata karyawan, kontrak psikologis pada karyawan berfokus pada evaluasi terhadap imbalan yang diberikan perusahaan dan bagaimana hal ini mempengaruhi tekad mereka untuk tetap berada di perusahaan (De Vos, Meganck, \& Buyens, 2005). Ketika karyawan mengevaluasi bahwa imbalan yang dijanjikan perusahaan tidak terpenuhi, pelanggaran kontrak psikologis terjadi dan manajemen retensi akan gagal. Jadi, dapat diasumsikan bahwa pelanggaran kontrak psikologis berhubungan positif dengan intensi turnover pada karyawan. Hal serupa juga dikemukakan Turnley dan Feldman (1998) bahwa persepsi akan adanya pelanggaran kontrak psikologis dapat mengarah pada keengganan untuk berkontribusi dalam perusahaan.

Selain fenomena mengenai manajemen retensi, fenomena lain yang umum terjadi di sebuah perusahaan adalah perbedaan tipe kepribadian karyawan, yang terkait erat dengan ciri yang menyertai masing-masing tipe kepribadian tersebut (Jamal \& Baba, 2001). Perbedaan tipe kepribadian ini dapat menyebabkan perbedaan kinerja karyawan (Matteson, Ivancevich, \& Smith, dalam Jamal \& Baba, 2001), hubungan sosialnya (Sims, 2002), dan juga stres kerjanya (Jamal \& Baba, 2003). Salah satu dari tipe kepribadian yang dapat menyebabkan perbedaan hasil kerja adalah kepribadian tipe A.

Kepribadian tipe A merupakan kompleks tindakan dan emosi yang dapat diamati dalam diri seseorang yang terlibat secara agresif dalam suatu perjuangan yang terusmenerus untuk selalu mencapai hasil yang lebih. Orang dengan kepribadian tipe A akan melakukan usaha yang bertentangan dari orang lain apabila diperlukan untuk mencapai apa yang diinginkan olehnya (Kreitner \& Kinicki, 2005). Beberapa ciri menonjol dari kepribadian tipe A adalah sangat berorientasi prestasi, terburu-buru, eksplosif dan agresif, suka menantang dan kompetitif (Jamal \& Baba, 2001). Kepribadian tipe A juga selalu berusaha memperoleh lebih dalam waktu sesingkat-singkatnya (Sims, 2002).

Menurut Friedman dan Rosenman (1974), orang dengan kepribadian tipe A memiliki harapan yang tinggi untuk mencapai kesuksesan. Orang dengan kepribadian tipe A juga kerap kali menghancurkan sebuah hubungan demi mengejar karir profesional. Karena itu, orang dengan kepribadian tipe A tidak akan segan meninggalkan perusahaannya jika merasa perusahaannya tak lagi memenuhi kriterianya. Selain itu, sifat kompetitif yang dibarengi dengan agresif pada orang dengan kepribadian tipe A membuatnya sering mengalami masalah sosial dan sulit untuk merasa nyaman di sebuah lingkungan kerja (Smitts, 2010), sehingga intensi turnover-nya diasumsikan tinggi. Orang berkepribadian tipe A juga sulit merasa puas (Sari dan Arruum, 2006). Hal itu membuat seseorang berkepribadian tipe A dapat mengambil tindakan keluar dari perusahaan karena secara umum, kepribadian tipe A berhubungan negatif dengan kepuasan kerja dan komitmen organisasi (Jamal \& Baba, 2001). Orang dengan kepribadian tipe A juga dianggap lebih memiliki kecenderungan untuk mengalami tingkat stres yang lebih tinggi sebab mereka 
menempatkan diri mereka sendiri pada suatu tekanan waktu dengan menciptakan suatu batas waktu tertentu untuk kehidupan mereka (Sutanto \& Djohan, 2006). Karakteristik negatif karyawan dengan kepribadian tipe A akan membuatnya bertindak atau merespon secara negatif, sehingga dapat memicu karyawan tersebut untuk keluar dari pekerjaannya.

Dua faktor yang telah disebutkan, yakni pelanggaran kontrak psikologis dan kepribadian tipe A sama-sama mengarah pada intensi turnover. Whitman (dalam Gbadamosi \& Chinaka, 2011) menyatakan bahwa intensi turnover merupakan pemikiran yang dimiliki oleh karyawan terkait meninggalkan perusahaan atas kehendaknya sendiri. Hal ini sejalan dengan pendapat Suwandi dan Indriantoro (1999) yang menyatakan intensi turnover sebagai keinginan individu untuk meninggalkan perusahaan dan mencari alternatif pekerjaan lain. Parasuraman (dalam Cohen \& Golan, 2007) menyatakan bahwa intensi turnover memainkan peranan penting dalam sikap terhadap turnover dan merupakan pencetus langsung dari turnover nyata. Hal ini juga diperkuat oleh pendapat Ajzen (dalam Gbadamosi \& Chinaka, 2011), yang menyebutkan bahwa intensi turnover berakibat buruk karena merupakan prediktor kuat turnover nyata. Seorang karyawan yang memiliki intensi turnover akan memiliki peluang besar untuk melakukan turnover nyata, sehingga dalam penelitian ini yang akan ditekankan adalah intensi turnover.

Bloomquist dan Kleiner (2000) menyatakan bahwa turnover menimbulkan beberapa kerugian antara lain berupa keluarnya banyak biaya meliputi biaya iklan, biaya wawancara calon karyawan, pengadaan karyawan, orientasi, pelatihan, dan biaya tambahan lainnya jika biaya turnover meningkat sehingga turnover memberikan efek atau pengaruh yang nyata bagi perusahaan. Karena itulah, perusahaan berupaya meminimalisir turnover yang terjadi. Di samping itu, turnover juga dapat membuat perusahaan kehilangan nama baiknya di mata konsumen dan karyawannya sendiri, sebagaimana yang dikemukakan oleh Level Playing Field Institute (2007). Di mata konsumen dan pihak luar, perusahaan terkesan tidak sanggup mempertahankan karyawannya di dalam perusahaan sekaligus menimbulkan persepsi bahwa karyawan diperlakukan dengan tidak baik. Selain itu, di mata karyawannya sendiri, perusahaan dipandang tidak mampu menyediakan keamanan kerja sehingga akan mengurangi motivasi karyawan di perusahaan tersebut. Dampak negatif turnover lainnya juga dikemukakan oleh Pisneacova (2011), yang menyebutkan bahwa selain membuat citra perusahaan menjadi buruk, tingginya turnover pada suatu perusahaan juga membuat para pencari kerja enggan melamar pekerjaan di perusahaan yang bersangkutan.

Turnover masih tetap terjadi dengan persentase yang cukup tinggi meski berdampak sedemikian negatif. Di Indonesia sendiri, tingginya angka turnover ditunjukkan oleh hasil survei Watson Wyatt yang dinyatakan di konferensi pers Global Strategic Reward (Suhendro, 2008). Menurut survei tersebut, pada tahun 2007 tingkat turnover di bidang perbankan untuk posisi-posisi penting, yakni level manajerial dan di atasnya mencapai $6,3 \%-7,5 \%$, padahal pada industri umumnya hanya $0,1 \%-0,74 \%$. Maka dari itu, tingginya tingkat turnover di bidang perbankan ini pun harus memperoleh perhatian serius, karena bisa berpengaruh terhadap efisiensi dan efektifitas dari bidang perbankan itu sendiri. Turnover karyawan dapat mengacaukan rencana dan strategi organisasi untuk mencapai tujuannya (Abasi \& Hollman, 2008), yang mana hal tersebut terkait dengan berkurangnya sumber daya manusia dan hilangnya staf dengan talenta yaang dibutuhkan oleh organisasi. Ketika sebuah organisasi kehilangan karyawannya, terdapat beberapa dampak meliputi berkurangnya level inovasi keseluruhan dan kualitas pelayanan pelanggan, yang terjadi karena berkurangnya motivasi karyawan untuk bekerja bagi organisasi (Miller, dalam Ahmad \& Omar, 2010).

Berdasarkan pertimbangan tersebut, peneliti ingin melihat hubungan antara pelanggaran kontrak psikologis dan kepribadian tipe A dengan intensi turnover karyawan bank, baik secara simultan maupun individual. Fokus dilakukan pada intensi turnover dengan pertimbangan bahwa intensi turnover merupakan pencetus langsung dari turnover nyata, sehingga bisa digunakan untuk memprediksi turnover nyata sekaligus menemukan hal-hal apa saja yang kiranya terkait dengan intensi turnover dan bagaimana strategi yang tepat untuk mengatasinya.

\section{METODE}

\section{Hipotesis}

Berdasarkan apa yang sudah diuraikan di latar belakang, peneliti mengajukan hipotesis mayor dan hipotesis minor untuk diteliti. Hipotesis mayor dalam penelitian ini adalah "terdapat hubungan positif yang signifikan antara pelanggaran kontrak psikologis dan kepribadian tipe A dengan intensi turnover karyawan bank." Hipotesis minor dalam penelitian ini adalah "terdapat hubungan positif yang signifikan antara pelanggaran kontrak psikologis dengan intensi turnover karyawan bank" dan "terdapat hubungan positif yang signifikan antara kepribadian tipe A dengan intensi turnover karyawan bank".

\section{Variabel dan definisi operasional}

Variabel penelitian adalah obyek yang mempunyai variasi tertentu yang ditetapkan oleh peneliti untuk dipelajari dan kemudian ditarik kesimpulannya (Sugiyono, 2012). Terdapat dua jenis variabel dalam penelitian ini, yaitu variabel bebas dan variabel tergantung. Variabel bebas merupakan 
variabel yang mempengaruhi atau yang menjadi sebab perubahan variabel dependen atau terikat (Sugiyono, 2012). Variabel bebas dalam penelitian ini adalah pelanggaran kontrak psikologis dan kepribadian tipe A. Variabel tergantung merupakan variabel yang dipengaruhi atau yang menjadi akibat, karena adanya variabel bebas (Sugiyono, 2012). Variabel tergantung dalam penelitian ini adalah intensi turnover.

Berikut ini adalah definisi operasional masing-masing variabel:

1. Definisi operasional pelanggaran kontrak psikologis

Pelanggaran kontrak psikologis adalah hasil evaluasi karyawan yang menemukan adanya kesenjangan antara apa yang dijanjikan pada karyawan dan apa yang sebenarnya diterima karyawan. Terdapat lima aspek pelanggaran kontrak psikologis, yaitu peluang pengembangan karir, konten pekerjaan, atmosfer sosial, imbalan finansial, dan keseimbangan kehidupan pribadi dan pekerjaan. Pelanggaran kontrak psikologis akan diukur dengan alat ukur yang diciptakan De Vos, Buyens, dan Schalk (2003), yang akan diadaptasi ke dalam bahasa Indonesia dan dimodifikasi sesuai kebutuhan. Kuesioner De Vos, Buyens, dan Schalk digunakan karena kuesioner tersebut memiliki validitas dan reliabilitas yang baik dan mengukur hal-hal yang umumnya dijanjikan oleh perusahaan sebagai dasar dari terbentuknya kontrak psikologis, sehingga dapat mengetahui bagaimana evaluasi karyawan akan apa yang dijanjikan oleh perusahaan.

2. Definisi operasional kepribadian tipe A

Kepribadian tipe A adalah tipe kepribadian yang ditandai dengan karakteristik berupa kompetitif, agresif, tidak sabar, rentan stres, tidak mudah puas, berorientasi prestasi, dan tergesa-gesa dalam pengambilan keputusan. Kepribadian tipe A akan diukur dengan dasar berupa aspek-aspek dari Jamal dan Baba (2001). Berikut ini adalah aspek dari kepribadian tipe A, yaitu tidak sabar, kompetitif, agresif, dan orientasi prestasi. Kepribadian tipe A akan diukur menggunakan kuesioner dengan bentuk pernyataan tertutup yang dibuat oleh peneliti dan sudah diuji validitas dan reliabilitasnya. Kuesioner tersebut akan mengukur sikap responden akan setiap pernyataan yang ada di dalamnya mengenai kepribadian tipe A. Pernyataan akan disesuaikan dengan aspek kepribadian tipe A dari Jamal dan Baba (2001).

\section{Definisi operasional intensi turnover}

Intensi turnover adalah keinginan dan pemikiran seseorang untuk keluar dari perusahaannya atas kehendaknya sendiri yang nampak dari ketertarikan mencari pekerjaan lain dan dorongan keluar dari perusahaan. Intensi turnover akan diukur dengan dasar berupa aspek-aspek dari Suwandi dan Indriantoro (1999). Terdapat dua aspek untuk mengukur intensi turnover yaitu tertarik untuk mencari pekerjaan lain sementara masih tergabung dalam perusahaan dan terdorong untuk meninggalkan perusahaan. Intensi turnover akan diukur menggunakan kuesioner dengan bentuk pernyataan tertutup yang dibuat oleh peneliti dan sudah diuji validitas dan reliabilitasnya. Kuesioner tersebut akan mengukur sikap responden akan setiap pernyataan yang ada di dalamnya mengenai intensi turnover. Pernyataan akan disesuaikan dengan aspek intensi turnover menurut Suwandi dan Indriantoro (1999).

\section{Responden}

Responden dipilih melalui teknik cluster random sampling dari populasi berupa karyawan bank di Bali. Dalam penelitian ini, respondennya adalah karyawan bank $\mathrm{X}$ yang jabatannya berada di bawah level manajerial, berjenis kelamin pria dan wanita, dan bukan merupakan karyawan outsourcing. Karyawan di bawah level manajerial dipilih karena survei Watson Wyatt (2007) telah meneliti yang berada di atas level manajerial. Di samping itu, jumlah karyawan di bawah level manajerial memiliki proporsi besar dalam perusahaan, sehingga riset tentang intensi turnover-nya penting untuk dilakukan. Semakin banyak karyawan di bawah level manajerial yang memiliki intensi turnover tinggi, maka semakin besar kerugian perusahaan. Karyawan dengan jenis kelamin pria dan wanita dipilih untuk menjaga agar tidak ada bias yang timbul dari perbedaan jenis kelamin. Karyawan yang merupakan karyawan outsourcing tidak disertakan dalam penelitian ini atas alasan originalitas karena penelitian mengenai intensi turnover karyawan outsourcing di bank telah dilakukan oleh Indraprasti (2012).

\section{Tempat penelitian}

Penelitian ini dilangsungkan di bank X di Denpasar, Bali, pada bulan November tahun 2012.

\section{Alat ukur}

Alat ukur dalam penelitian ini adalah kuesioner. Kuesioner pengukur intensi turnover dan kepribadian tipe A dibuat sendiri oleh peneliti berdasarkan aspek yang sudah disebutkan di definisi operasional. Kuesioner pelanggaran kontrak psikologis diadaptasi dan dimodifikasi sesuai kebutuhan dari kuesioner buatan De Vos, Buyens, dan Schalk (2003). Setiap kuesioner memiliki empat pilihan jawaban, yakni 'sangat tidak setuju', 'tidak setuju', 'setuju', dan 'sangat setuju' untuk mengukur persetujuan terhadap pernyataan dalam kuesioner.. Empat alternatif jawaban tersebut merupakan jenis Likert termodifikasi dengan menghilangkan pilihan jawaban netral atau ragu-ragu, yang bertujuan agar 
subyek penelitian menjawab dengan pasti dan sesuai dengan dirinya ( Hadi, 1984).

Sebelum diberikan pada responden penelitian, alat ukur telah diujicobakan terlebih dahulu kepada 45 orang karyawan bank Y untuk mengetahui validitas dan reliabilitasnya. Validitas yang ditinjau dalam penelitian ini adalah validitas isi dan validitas konstruk. Reliabilitas diuji dengan pendekatan konsistensi internal. Validitas isi diuji dengan menggunakan teknik professional judgement yaitu memberikan kuesioner kepada dosen pembimbing skripsi untuk dilihat kesahihan tiap butir pernyataannya. Validitas konstruk diuji dengan melihat nilai rix (corrected item-total correlation) dengan batas toleransi 0,30. Pengujian reliabilitas konsistensi internal dilakukan dengan menggunakan teknik Cronbach's alpha dibantu program SPSS 17.

Setelah melalui tahap pengujian validitas dan reliabilitas tersebut, ditemukan bahwa kuesioner intensi turnover memiliki 23 item sahih dengan koefisien reliabilitas 0,896, kuesioner pelanggaran kontrak psikologis memiliki 18 item sahih dengan koefisien reliabilitas 0,870, dan kuesioner kepribadian tipe A memiliki 35 item sahih dengan koefisien reliabilitas 0,965 .

\section{Metode pengumpulan data}

Pengumpulan data akan menentukan kualitas data yang digunakan untuk menentukan hasil penelitian nantinya, sehingga perlu dilakukan dengan baik. Dalam penelitian ini, pengumpulan data dilakukan dengan cara melakukan pengukuran terhadap tiga variabel penelitian, yaitu pelanggaran kontrak psikologis, kepribadian tipe A, dan intensi turnover. Seluruh variabel diukur dengan kuesioner. Pengumpulan data dilakukan dengan menyebarkan kuesioner ke bank $X$ yang karyawannya terpilih sebagai sampel dalam penelitian ini melalui cluster random sampling dari populasi berupa karyawan bank di Bali. Sebelum kuesioner disebarkan, bank diberitahu bahwa data yang dikumpulkan akan dijaga kerahasiaannya dengan jalan menjaga anonimitas nama responden. Setelah pengambilan data disetujui, barulah peneliti menyebarkan kuesioner dengan jalan menitipkannya pada bagian personalia bank. Begitu seluruh kuesioner terkumpul, peneliti mengambil kembali kuesioner yang dititipkan dan memasukkan seluruh data ke dalam program SPSS 17 untuk diolah.

\section{Teknik analisis data}

Secara spesifik, penelitian ini merupakan bentuk studi korelasional dengan metode analisis regresi ganda dan korelasi parsial. Regresi ganda dilakukan untuk melihat hubungan pelanggaran kontrak psikologis dan kepribadian tipe A dengan intensi turnover secara simultan sekaligus melihat kontribusinya. Regresi ganda yang dilakukan menggunakan metode enter. Korelasi parsial dilakukan untuk melihat hubungan masing-masing variabel bebas yaitu pelanggaran kontrak psikologis dan kepribadian tipe A dengan intensi turnover secara individual. Analisis data dilakukan dengan menggunakan program bantu SPSS 17.

\section{HASIL PENELITIAN}

Sebelum melihat apakah terdapat hubungan antara variabel-variabel yang ingin diteliti, peneliti melakukan uji asumsi yang meliputi uji normalitas dan uji linearitas untuk memastikan bahwa data memang layak dan bisa digunakan dalam penelitian.

Dalam penelitian ini, uji normalitas dilakukan dengan menggunakan Kolmogorov-Smirnov SPSS 17. Suatu data dapat dikatakan normal apabila hasil uji normalitasnya berada di atas taraf signifikansi 0,05 . Hasil pengujian dapat dilihat pada tabel berikut:

\section{Tabel 1}

Hasil Uji Normalitas

\begin{tabular}{cccc}
\hline & $\begin{array}{c}\text { Intensi } \\
\text { turnover }\end{array}$ & $\begin{array}{c}\text { Pelanggaran } \\
\text { Kontrak } \\
\text { Psikologis }\end{array}$ & $\begin{array}{c}\text { Kepribadian } \\
\text { tipe A }\end{array}$ \\
\hline $\begin{array}{c}\text { Kolmogorov- } \\
\text { Smirnov Z }\end{array}$ & 1.211 & 1.188 & 1.103 \\
Asymp. & 0,106 & 0,119 & 0,176 \\
Significant & & & \\
\hline
\end{tabular}

Seluruh variabel memiliki taraf signifikansi di atas 0,05, sehingga semua variabel dinyatakan memiliki distribusi data normal. Selain itu, dilakukan pula uji linearitas untuk melihat apakah hubungan antara satu variabel dependen dengan variabel independen bersifat linear. Asumsi linearitas dapat diuji menggunakan compare means dengan SPSS 17. Apabila signifikansinya berada di bawah taraf signifikansi 0,05 , maka hubungannya dinyatakan linear.

Tabel 2

Hasil Uji Linearitas Intensi Turnover dan Pelanggaran Kontrak Psikologis

\begin{tabular}{ccccc}
\hline & & & F & Signifikansi \\
\hline ITO*PKP & Between & (Combined) & 10,194 & 0,000 \\
& Groups & Linearity & 200,000 & 0,000 \\
& & Deviation from Linearity & 3,416 & 0,002 \\
\hline
\end{tabular}

Tabel 3

Hasil Uji Linearitas Intensi Turnover dan Kepribadian Tipe A

\begin{tabular}{ccccc}
\hline & & & F & Signifikansi \\
\hline ITO*KA & Between & (Combined) & 10,316 & 0,000 \\
& Groups & Linearity & 258,059 & 0,000 \\
& & Deviation from Linearity & 2,324 & 0,029 \\
\hline
\end{tabular}


Hasil pengujian menunjukkan bahwa baik hubungan pelanggaran kontrak psikologis dan kepribadian tipe A dengan intensi turnover bersifat linear karena memiliki signifikansi sebesar 0,000, yang lebih kecil dari taraf sinifikansi 0,05.

Hubungan pelanggaran kontrak psikologis dan kepribadian tipe A secara simultan dengan intensi turnover dilihat dengan regresi ganda dengan bantuan SPSS 17. Berikut adalah hasil dari uji regresi ganda:

\begin{tabular}{|c|c|c|c|c|c|c|}
\hline & \multirow[b]{4}{*}{ Model } & \multicolumn{3}{|c|}{ Tabel 4} & & \multirow{5}{*}{$\frac{\text { Sig. }}{000^{\mathrm{a}}}$} \\
\hline & & \multicolumn{3}{|c|}{ Hasil Uji Regresi Ganda } & \multirow{4}{*}{$\frac{F}{71.212}$} & \\
\hline & & \multicolumn{3}{|c|}{ ANOVA $^{\mathrm{b}}$} & & \\
\hline & & $\begin{array}{l}\text { Sum of } \\
\text { Squares }\end{array}$ & df & Mean Square & & \\
\hline \multirow[t]{3}{*}{1} & Regression & 11642.889 & 2 & 5821.444 & & \\
\hline & Residual & 4005.631 & 49 & 81.748 & & \\
\hline & Total & 15648.519 & 51 & & & \\
\hline
\end{tabular}

a. Predictors: (Constant), KA, PKP

b. Dependent Variable: ITO

Nilai $F$ adalah 71,212 dengan besar signifikansi 0,000. Maka dari itu, dapat dinyatakan bahwa terdapat hubungan signifikan antara variabel pelanggaran kontrak psikologis dan variabel kepribadian tipe A dengan variabel intensi turnover. Nilai signifikansi sebesar 0,000 juga menyatakan bahwa garis regresi dapat dipercaya untuk meramalkan kontribusi variabel independen yakni pelanggaran kontrak psikologis dan kepribadian tipe A terhadap variabel dependen yakni intensi turnover. Besar korelasi dan kontribusi variabel pelanggaran kontrak psikologis dan variabel kepribadian tipe A dalam memprediksi variabel intensi turnover dapat dilihat dari tabel di bawah ini:

Tabel 5

Hasil Uji R ${ }^{2}$

\begin{tabular}{|c|c|c|c|c|}
\hline \multicolumn{5}{|c|}{ Model Summary } \\
\hline & & & Adjusted R & Std. Error of the \\
\hline Model & $\mathrm{R}$ & R Square & Square & Estimate \\
\hline 1 & $.863^{\mathrm{a}}$ & .744 & .734 & 9.04144 \\
\hline
\end{tabular}

Besarnya hubungan pelanggaran kontrak psikologis dan kepribadian tipe A terhadap intensi turnover dapat dilihat dari nilai R-nya yakni 0,863 yang mana tergolong kuat menurut rentang yang diajukan oleh Boediono dan Koster (2004). Nilai R juga bersifat positif, sehingga menyatakan bahwa memang terdapat hubungan yang positif antara pelanggaran kontrak psikologis dan kepribadian tipe A dengan intensi turnover.
Nilai kontribusi pelanggaran kontrak psikologis dan kepribadian tipe A terhadap intensi turnover dapat dilihat dari koefisien determinasi simultannya $\left(\mathrm{R}^{2}\right)$. Dari tabel tersebut dapat dilihat nilai $\mathrm{R}^{2}$ sebesar 0,744 , yang berarti pelanggaran kontrak psikologis dan kepribadian tipe A secara bersamaan berkontribusi terhadap intensi turnover sebesar $74,4 \%$. Sebanyak 25,6\% dijelaskan oleh variabel lain yang tidak diteliti dalam penelitian ini. Nilai adjusted $R$ square sebesar 0,734 menunjukkan bahwa jika model regresi diterapkan pada populasi, maka kontribusinya adalah sebesar 73,4\%. Sementara itu, untuk melihat hubungan pelanggaran kontrak psikologis dan kepribadian tipe A dengan intensi turnover secara individual, digunakan korelasi parsial. Berikut adalah hasil korelasi parsial yang diperoleh:

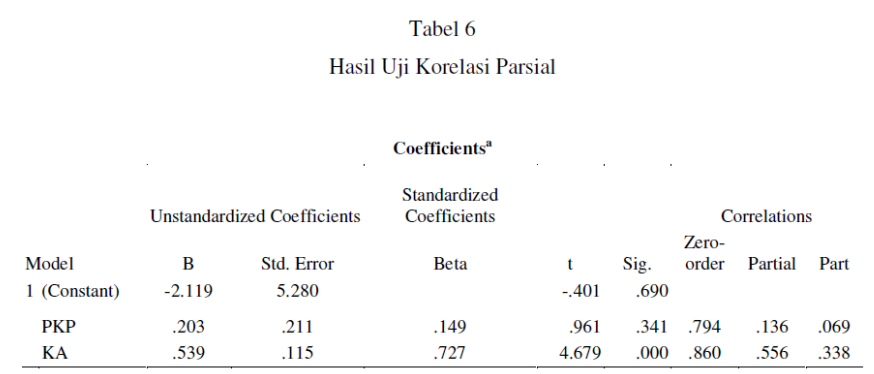

Variabel pelanggaran kontrak psikologis memiliki besar nilai korelasi parsial 0,136. Nilai signifikansi sebesar 0,341 menyatakan bahwa variabel pelanggaran kontrak psikologis tidak memiliki hubungan dengan variabel intensi turnover karena signifikansinya berada di atas 0,05. Variabel kepribadian tipe A memiliki besar nilai korelasi parsial 0,556. Nilai signifikansi sebesar 0,000 menyatakan bahwa kepribadian tipe A memiliki hubungan yang signifikan dengan intensi turnover. Nilai korelasi yang positif menunjukkan bahwa terdapat hubungan positif antara kepribadian tipe A dengan intensi turnover. Jadi, hanya variabel kepribadian tipe A yang berhubungan positif signifikan dengan variabel intensi turnover.

Peneliti juga melakukan pengkategorisasian skor untuk menambah hasil dalam analisis data penelitian. Kategorisasi dilakukan untuk melihat subyek yang memiliki skor paling tinggi dan rendah pada masing-masing variabel. Penggolongan ini bertujuan untuk menempatkan subyek ke dalam kelompok yang terpisah secara berjenjang menurut kontinum berdasarkan atribut yang diukur (Azwar, 2010).

\begin{tabular}{cc}
\multicolumn{2}{c}{ Tabel 7} \\
\multicolumn{2}{c}{ Rumus Kategorisasi Skor } \\
\hline Skor & Kategorisasi \\
\hline$X \leq(\mu-1,5 \sigma)$ & Sangat Rendah \\
$(\mu-1,5 \sigma)<X \leq(\mu-0,5 \sigma)$ & Rendah \\
$(\mu-0,5 \sigma)<X \leq(\mu+0,5 \sigma)$ & Sedang \\
$(\mu+0,5 \sigma)<X \leq(\mu+1,5 \sigma)$ & Tinggi \\
$(\mu+1,5 \sigma)<X$ & Sangat Tinggi \\
\hline
\end{tabular}


Dengan panduan rumus tersebut, peneliti mengkategorikan skor tiap variabel dalam penelitian ini. Variabel pelanggaran kontrak psikologis memiliki skor minimal 21 dan skor maksimal 67, dengan rentang skor 46 . Standar deviasinya adalah sebesar 12,9 dengan mean teoritis sebesar 44. Hasil kategorisasinya adalah sebagai berikut:

Tabel 8

Hasil Kategorisasi Variabel Pelanggaran Kontrak Psikologis

\begin{tabular}{cccc}
\hline Variabel & Rentang Nilai & Kategori & Subyek \\
\hline Pelanggaran & $\mathrm{X} \leq 24,65$ & Sangat Rendah & 1 orang \\
kontrak & $24,65 \leq \mathrm{X} \leq 37,55$ & Rendah & 9 orang \\
psikologis & $37,55 \leq \mathrm{X} \leq 50,45$ & Sedang & 22 orang \\
& $50,45 \leq \mathrm{X} \leq 63,35$ & Tinggi & 13 orang \\
& $63,35<\mathrm{X}$ & Sangat Tinggi & 7 orang \\
& Jumlah & & 52 orang \\
\hline
\end{tabular}

Analisis kategorisasi variabel pelanggaran kontrak psikologis menunjukkan bahwa subjek yang termasuk dalam kategori sangat rendah ada 1 orang, kategori rendah ada 9 orang, kategori sedang ada 22 orang, kategori tinggi ada 13 orang, dan kategori sangat tinggi ada 7 orang. Jadi secara dominan, pelanggaran kontrak psikologis subyek sedang.

Variabel kepribadian tipe A memiliki skor minimal 48 dan skor maksimal 129, dengan rentang skor 81. Standar deviasinya adalah sebesar 23,6 dengan mean teoritis sebesar 88,5 . Hasil kategorisasinya adalah sebagai berikut:

Tabel 9

Hasil Kategorisasi Variabel Kepribadian Tipe A

\begin{tabular}{cccc}
\hline Variabel & Rentang Nilai & Kategori & Subyek \\
\hline Kepribadian Tipe & $\mathrm{X} \leq 53,1$ & Sangat Rendah & 4 orang \\
$\mathrm{A}$ & $53,1 \leq \mathrm{X} \leq 76,7$ & Rendah & 3 orang \\
& $76,7 \leq \mathrm{X} \leq 100,3$ & Sedang & 23 orang \\
& $100,3 \leq \mathrm{X} \leq 123,9$ & Tinggi & 17 orang \\
& $123,9<\mathrm{X}$ & Sangat Tinggi & 5 orang \\
& Jumlah & & 52 orang \\
\hline
\end{tabular}

Analisis kategorisasi variabel kepribadian tipe A menunjukkan bahwa subjek yang termasuk dalam kategori sangat rendah ada 4 orang, kategori rendah ada 3 orang, kategori sedang ada 23 orang, kategori tinggi ada 17 orang, dan kategori sangat tinggi ada 5 orang. Jadi, secara dominan, subyek memiliki kecenderungan kepribadian tipe A sedang.

Variabel intensi turnover memiliki skor minimal 32 dan skor maksimal 83, dengan rentang skor 51. Standar deviasinya adalah sebesar 17,5 dengan mean teoritis sebesar 57,5. Hasil kategorisasinya adalah sebagai berikut:
Tabel 10

Hasil Kategorisasi Variabel Intensi Turnover

\begin{tabular}{cccc}
\hline Variabel & Rentang Nilai & Kategori & Subyek \\
\hline Intensi turnover & $\mathrm{X} \leq 31,25$ & Sangat Rendah & 0 orang \\
$31,25 \leq \mathrm{X} \leq 48,75$ & Rendah & 17 orang \\
$48,75 \leq \mathrm{X} \leq 66,25$ & Sedang & 13 orang \\
$66,25 \leq \mathrm{X} \leq 83,75$ & Tinggi & 22 orang \\
$83,75<\mathrm{X}$ & Sangat Tinggi & 0 orang \\
& Jumlah & & 52 orang \\
\hline
\end{tabular}

Analisis kategorisasi variabel intensi turnover menunjukkan bahwa subjek yang termasuk dalam kategori rendah ada 17 orang, kategori sedang ada 13 orang, dan kategori tinggi ada 22 orang. Tidak ada subyek yang termasuk dalam kategori sangat rendah dan sangat tinggi. Jadi, secara dominan subyek memiliki intensi turnover tinggi.

\section{PEMBAHASAN}

Sebagaimana yang telah dikemukakan, hasil penelitian ini menunjukkan bahwa secara signifikan terdapat hubungan antara pelanggaran kontrak psikologis dan kepribadian tipe A dengan intensi turnover karyawan bank. Besar hubungan pelanggaran kontrak psikologis dan kepribadian tipe A dengan intensi turnover adalah 0,863. Nilai tersebut positif sehingga dinyatakan bahwa ada hubungan positif antara pelanggaran kontrak psikologis dan kepribadian tipe A dengan intensi turnover karyawan bank. Dilihat dari nilai koefisien determinasi simultannya, pelanggaran kontrak psikologis dan kepribadian tipe A berkontribusi terhadap intensi turnover sebesar 74,4\%, sementara $25,6 \%$ sisanya ditentukan oleh variabel lain. Dari uraian tersebut, dapat dinyatakan bahwa hipotesis mayor yang berbunyi "terdapat hubungan positif yang signifikan antara pelanggaran kontrak psikologis dan kepribadian tipe A dengan intensi turnover karyawan bank" diterima.

Hal tersebut terjadi karena karyawan yang merasa mengalami pelanggaran kontrak psikologis dan sekaligus memiliki kepribadian tipe A akan cenderung memiliki intensi turnover yang tinggi. Pelanggaran kontrak psikologis membuat karyawan merasa diperlakukan secara tidak adil dan pada akhirnya memicu sikap negatif pada perusahaan. Sebagaimana yang dikemukakan oleh You dan Shim (2012), karyawan yang mengalami pelanggaran kontrak psikologis akan merasa kecewa, yang akhirnya mengarah pada perubahan sikap dan perilaku kerja, berupa berkurangnya komitmen dan perilaku kewargaan organisasi dan terlibat dalam perilaku anti organisasi. Sikap negatif pada perusahaan ini dapat mendorong seorang karyawan untuk keluar dari perusahaannya.

Karyawan dengan kepribadian tipe A yang secara umum memang memiliki ciri tidak sabar dan agresif (Iswati, 2008), akan lebih mudah memiliki perasaan negatif terhadap 
perusahaan ketika terjadi pelanggaran kontrak psikologis. Adanya pelanggaran kontrak psikologis yang dimiliki karyawan berkepribadian tipe A terhadap perusahaannya dapat memicu munculnya pemikiran untuk meninggalkan perusahaan karena karyawan tersebut tidak cukup sabar untuk melakukan proses negosiasi dan lainnya. Karyawan yang bersangkutan juga agresif, di mana karyawan tersebut akan memiliki emosi negatif yang lebih besar dan lebih sulit menerima keadaan apabila terjadi pelanggaran kontrak psikologis, sehingga memunculkan intensi turnover. Koping yang dipilih karyawan dengan kepribadian tipe A cenderung bersifat maladaptif, sebagaimana yang dinyatakan Chen (dalam Sari dan Arruum, 2006). Koping maladaptif dapat ditunjukkan dengan melakukan penghindaran (avoidance), marah, hingga pemutusan hubungan (Buettener, dalam Sari dan Arruum, 2006).

Selain itu, sesuai ciri kepribadian tipe A yang dikemukakan Price (1981), karyawan berkepribadian tipe A kurang peduli pada prinsip moral, yang mana seseorang dengan kepribadian tipe A akan melakukan apa yang dianggapnya penting untuk memperoleh keadilan bagi dirinya sendiri meskipun harus menempuh jalan yang berlawanan dengan norma yang ada. Ketika kontrak psikologisnya dilanggar dan muncul perasaan diperlakukan tidak adil, karyawan berkepribadian tipe A akan memiliki niat untuk keluar dari perusahaan. Hal ini terjadi karena karyawan berkepribadian tipe A memang memiliki komitmen yang rendah pada perusahaannya (Jamal \& Baba, 2001). Jadi, mereka enggan bertahan di perusahaan karena merasa tidak memiliki utang budi dan tanggung jawab moral pada perusahaan, atau disebut juga komitmen normatif (Allen \& Meyer, 2000). Maka dari itu, gabungan kepribadian tipe A dengan pelanggaran kontrak psikologis dapat memicu terjadinya intensi turnover.

Dalam penelitian ini diketahui bahwa nilai koefisien determinasi simultannya $\left(\mathrm{R}^{2}\right)$ adalah 0,744 . Nilai ini memiliki arti bahwa sumbangan efektif pelanggaran kontrak psikologis dan kepribadian tipe A terhadap intensi turnover adalah sebesar 74,4\%. Sedangkan 25,6\% dipengaruhi oleh variabelvariabel lain di luar variabel yang diteliti. Variabel-variabel lain tersebut ialah komitmen berkelangsungan, yang merupakan bertahannya karyawan di sebuah perusahaan karena mempertimbangkan mengenai biaya dan kerugian yang dirasakan karyawan jika dirinya meninggalkan pekerjaannya di perusahaan yang bersangkutan (Meyer \& Allen, 1997). Karyawan dengan komitmen berkelangsungan yang kuat akan meneruskan keanggotaannya di sebuah perusahaan hanya karena mereka membutuhkannya (Witasari, 2009). Jenkins, Thomlinson, dan Paul (dalam Witasari, 2009) menemukan bahwa bentuk komitmen berkelanjutan berhubungan dengan meningkatnya intensi turnover karyawan.
Variabel lain yang terkait dengan intensi turnover adalah tekanan yang terjadi di tempat kerja (Price, 2001). Seseorang akan memiliki intensi turnover yang tinggi apabila tekanan kerjanya juga tinggi. Tekanan kerja terkait dengan ambiguitas peran, konflik peran, dan beban kerja (Price, 2001). Seseorang yang mengalami level tekanan kerja tinggi di salah satu atau lebih dimensi itu akan memiliki intensi turnover yang lebih tinggi dibandingkan dengan yang level tekanan kerjanya sedang atau rendah.

Variabel terakhir adalah persepsi terhadap kecenderungan kepemimpinan otoriter. Penelitian yang dilakukan Kurniati, Rustam, dan Partini (2007) menemukan bahwa persepsi terhadap kecenderungan kepemimpinan otoriter memiliki hubungan positif dengan intensi turnover. Berbagai sikap yang terkait dengan gaya kepemimpinan otoriter seperti kebiasaan pemberian hukuman dan sikap acuh tak acuh dapat menimbulkan ketegangan dan ketidaknyamanan karyawan, yang akhirnya memicu intensi turnover.

Selain melihat hubungan kedua variabel secara simultan, peneliti juga ingin melihat hubungan pelanggaran kontrak psikologis dan kepribadian tipe A secara individual dengan intensi turnover karyawan bank. Berdasarkan uraian di hasil korelasi parsial, nilai signifikansi uji hubungan pelanggaran kontrak psikologis dan intensi turnover berada di atas $0,05(0,341)$ sehingga hubungannya dinyatakan tidak signifikan. Maka dari itu, dapat dinyatakan bahwa hipotesis minor yang berbunyi "terdapat hubungan positif yang signifikan antara pelanggaran kontrak psikologis dengan intensi turnover karyawan bank" ditolak.

Nilai signifikansi uji hubungan kepribadian tipe A dengan intensi turnover berada di bawah 0,05 (0,000), sehingga hubungannya dinyatakan signifikan. Besarnya hubungan dan arah hubungan kepribadian tipe A dengan intensi turnover ditunjukkan oleh nilai korelasi parsial sebesar 0,556 yang bernilai positif, sehingga hubungannya dinyatakan positif. Dari uraian tersebut, dapat dinyatakan bahwa hipotesis minor yang berbunyi "terdapat hubungan positif yang signifikan antara kepribadian tipe A dengan intensi turnover karyawan bank" diterima.

Tidak adanya hubungan antara pelanggaran kontrak psikologis dan intensi turnover terkait dengan apa yang dikemukakan di dalam riset Restubog, Bordia, dan Bordia (dalam You dan Shim, 2012), yang menyatakan bahwa pelanggaran kontrak psikologis diasosiasikan dengan perilaku pengabaian. Orang yang mengalami pelanggaran kontrak psikologis akan cenderung memilih perilaku berupa pengabaian akan pekerjaan daripada keluar (turnover). Perilaku pengabaian ini muncul dalam bentuk menelantarkan pekerjaan atau terlambat datang ke tempat kerja. Hal ini dapat terjadi karena adanya ketakutan untuk mencari pekerjaan baru atau adanya learned helplessness terhadap pekerjaan saat ini. 
Seorang karyawan yang mengalami pelanggaran kontrak psikologis dan tidak dapat melakukan apa pun untuk membuat kondisi lebih baik akhirnya merasa tidak berdaya dan memilih tetap menempatkan diri dalam kondisi kerja yang dirasa aversif (tidak menyenangkan).

Kepribadian tipe A ditemukan berhubungan dengan intensi turnover terkait dengan apa yang dijelaskan Iswati (2008). Orang berkepribadian tipe A memiliki ciri agresif dan tidak sabar sehingga kerapkali memiliki intensi keluar (turnover) dari perusahaan jika terjadi suatu masalah. Di samping itu, orang dengan kepribadian tipe A memiliki kecenderungan sulit untuk merasa puas (Sari dan Arruum, 2006), sehingga selalu berusaha untuk mencari yang terbaik. Apabila dalam perjalanan karirnya seseorang dengan kepribadian tipe A menemukan peluang karir yang lebih baik atau merasa pekerjaannya yang sekarang tidak menjanjikan, maka orang tersebut akan memiliki keinginan keluar dari perusahaan untuk mencari perusahaan atau pekerjaan lain yang sanggup memberikan kesempurnaan.

Selain itu, orang dengan kepribadian tipe A juga berorientasi prestasi dan kompetitif, bahkan dengan dirinya sendiri. Seseorang dengan kepribadian tipe A akan berupaya untuk menduduki peringkat teratas. Semakin sulit sebuah pekerjaan, semakin tertantang orang dengan kepribadian tipe A (O’Flynn-Comiskey, dalam Rayburn \& Rayburn, 1996). Ketika pekerjaan sudah tidak lagi dirasa memberikan prestasi yang mampu dibanggakan dan tidak lagi menantang, maka orang berkepribadian tipe A akan mencari pekerjaan baru yang dapat memenuhi standarnya. Selain itu, sifat kompetitif yang dibarengi dengan agresif pada orang berkepribadian tipe A membuatnya sering mengalami masalah sosial dan sulit untuk merasa nyaman di sebuah lingkungan kerja (Smitts, 2010), dan akhirnya mendorongnya melakukan turnover.

Jadi, dapat disimpulkan bahwa terdapat hubungan positif yang signifikan antara pelanggaran kontrak psikologis dan kepribadian tipe A dengan intensi turnover, dengan koefisien korelasi $+0,863$. Koefisien determinsi bernilai 0,744 menyatakan bahwa secara simultan, pelanggaran kontrak psikologis dan kepribadian tipe A berkontribusi terhadap intensi turnover sebesar 74,4\%. Terdapat pula hubungan positif yang signifikan antara kepribadian tipe A dengan intensi turnover, dengan koefisien korelasi +0,556. Namun, tidak terdapat hubungan antara pelanggaran kontrak psikologis dengan intensi turnover. Terkait dengan apa yang dikemukakan, bank dapat mengelola kesejahteraan karyawan dengan mempertimbangkan janji yang diberikan pada karyawan dan meninjau pemenuhannya terkait kontrak psikologis yang dimiliki karyawan. Dalam proses penempatan karyawan, bank dapat menempatkan karyawan berkepribadian tipe A di bidang yang menantang dan sesuai dengan tipe kepribadian tersebut sesuai dengan konsep personality-job fit untuk menambah kenyamanan kerja, mengeksplorasi potensi terbaik karyawan dengan kepribadian tipe A, serta meminimalisir intensi turnover. Bank juga dapat melakukan pelatihan pengendalian emosi, manajemen waktu, dan manajemen stres bagi karyawannya, khususnya yang berkepribadian tipe A, dengan harapan pelatihan tersebut dapat mengurangi intensi turnover.

Kepada karyawan bank, apabila merasakan adanya pelanggaran kontrak psikologis, daripada mengeluh dan terus mengabaikan pekerjaan, maka karyawan bisa melakukan tindakan progresif dan positif yang berupa bernegosiasi dan menuntut apa yang menjadi haknya sebab hal itu merupakan bagian dari kesepakatan antara karyawan dan perusahaan agar perusahaan tetap berjalan dengan lancar. Sementara itu, bagi karyawan bank dengan kepribadian tipe A, diharapkan secara sadar dan tanpa paksaan atau dengan kerelaaan untuk mengikuti program pelatihan pengendalian emosi, manajemen waktu, dan manajemen stres agar dapat membuat keputusan secara lebih rasional, bijaksana, dan tepat terkait keanggotaan di perusahaan. Kepada peneliti selanjutnya, disarankan untuk menggunakan rumus pengambilan jumlah sampel dalam menentukan sampel yang digunakan agar diperoleh sampel yang lebih representatif terhadap populasi. Disarankan juga untuk melihat variabel atau faktor lain yang terkait dengan intensi turnover agar dapat memperkaya literatur mengenai intensi turnover sendiri, mengingat kontribusi variabel pelanggaran kontrak psikologis dan kepribadian tipe A terhadap intensi turnover hanya sebatas $74,4 \%$ dan sisanya ditentukan variabel lain. Dari segi metodologi penelitian, disarankan untuk mengembangkan alat ukur yang juga melihat sisi positif dan potensi optimal dari kepribadian tipe A. Dengan demikian, alat ukur akan mampu melihat kepribadian tipe A secara lebih utuh dan berimbang, tidak hanya berpatokan pada aspek negatifnya semata. Disarankan juga untuk melakukan wawancara dan observasi untuk memperoleh data yang lebih mendalam.

\section{DAFTAR PUSTAKA}

Abbasi, S.M., Hollman, K.W., \& Hayes, R.D. (2008). BadBosses and How Not To Be One [Electronic version]. Information Management Journal, 42(1), 52-56.

Ahmad A., \& Omar, Z. (2010). Perceived Family-Supportive Work Culture, Affective Commitment and Turnover Intention of Employees [Electronic version]. Journal of American Science, 6 (12), 839-846.

Allen, N. J., \& Meyer, J. P. (2000). Construct validation in organizational behavior research: The case of organizational commitment [Electronic version]. Problems and solutions in human assessment: Honouring Douglas N. Jackson at seventy, $285-314$.

Azwar. S. (2010). Reliabilitas dan Validitas (3rd ed.). Yogyakarta: Pustaka Pelajar Offset.

Bal, P. M., Cooman, R. D., \& Mol, S. T. (2011). Dynamics of 
psychological contracts with work engangement and tirnover intention: The influence of organization tenure [Electronic version]. European Journal of Work and Organizational Psychology, 1-30, dari http://dx.doi.org/10.1080/1359432X.2011.626198

Bloomquist, M. J., \& Kleiner, B. H. (2000). How to reduce theft and turnover through better hiring methods [Electronic version]. Management Research News, 23, 7-8.

Boediono., \& Koster, W. (2004). Teori dan Aplikasi Statistika dan Probabilitas. Bandung: PT Remaja Rosdakarya.

Cohen, A., \& Golan, R. (2007). Predicting absenteeism and turnover intentions by past absenteeism and work attitudes: An empirical examination of female employees in long term nursing care facilities [Electronic version]. Career Development International, 12 (5), 416-432.

De Vos, A., Buyens, D., \& Schalk, R. (2003). Psychological contract development during organizational socialization: Adaptation to reality and the role of reciprocity [Electronic version]. Journal of Organizational Behavior, 24 (5), 537-599.

De Vos, A., Meganck, A., \& Buyens, D. (2005). The role of the psychological contract in retention management: confronting HR-managers' and employees' views on retention factors and the relationship with employees' intentions to stay [Electronic version]. Vlerick Leuven Gent Working Paper Series, dari http://www.feb.ugent.be/nl/Ondz/wp/Papers/wp_06_374.pdf.

Friedman, M., \& Rosenman, R. H. (1974). Type A behavior and your heart. New York: Knopf.

Gbadamosi, L., \& Chinaka, N. J. (2011). Organizational Politics, Turnover Intention and Organizational Commitments as Predictors of Employees' Efficiency and Effectiveness in Academia [Electronic version]. Proceedings of Informing Science \& IT Education Conference.

Gómez-Mejía, Balkin, \& Cardy. (2010). Managing Human Resources (6th ed.). New Jersey: Pearson Education, Inc.

Indraprasti, D. (2012). Pengaruh komitmen organisasional, kepuasan kerja, dan stres kerja terhadap intensi keluar studi pada karyawan alih daya (outsourcing) PT Bank Rakyat Indonesia di wilayah Yogyakarta. Tesis yang tidak diterbitkan, Universitas Gadjah Mada.

Iswati, S. (2008). Pengaruh komitmen profesional, tipe kepribadian, gender terhadap kepuasan kerja akuntan publik [Electronic version]. Ekuitas, 12 (1), 36-51.

Jamal, M., \& Baba, V. (2001). Type-A behavior, job performance, and well-being in college teachers [Electronic version]. International Journal of Stress Management, 8, 231-240.

Jamal, M., \& Baba, V. (2003). Type A behavior, components, and outcomes: A study of Canadian employees [Electronic version]. Journal of International Stress Management, 10, 39-50.

Kreitner, R. \& Kinicki, A. (2005). Perilaku Organisasi 1. Jakarta: Salemba Empat.

Kurniati, S., Rustam, A., \& Partini. (2007). Hubungan antara persepsi terhadap kecenderungan kepemimpinan otoriter dengan intensi turn over. Indigenous, Jurnal Ilmiah Berkala Psikologi, 9 (2), 84-91.

Level Playing Field Institute. (2007). The cost of employee turnover due solely to unfairness in the workplace. Diambil dari Level Playing Field Institute: https://www.lpfi.org/sites/default/files/corporate-leaverssurvey.pdf

Martin, J. (2005). Organisational Behaviour and Management (3rd ed.). Italy: G. Canale \& C.

Meyer, J. P., \& Allen, N. J. (1997). Commitment in the workplace: Theory, research, and application. Thousand Oaks: Sage Publishing, Inc.

Oracle. (2012). Talent retention: Six technology-enabled best practices [White paper]. Diambil dari Oracle Corporation: http://www.oracle.com/us/media1/talent-retention-6-bestpractices-1676595.pdf

Pisneacova, X. (2011). Motivation in organizations. Diambil 31 Januari 2013, dari

http://offadm.no/uploads/fagressurser/oadm1001/Semesteroppga ve\%20-\%20Motivation\%20in\%20organizations.pdf

Price, J. L. (2001). Reflections on the determinants of voluntary turnover [Electronic version]. International Journal of Manpower, 22 (7), 660-624.

Rayburn, M., \& Rayburn, L. (1996). Relationship between Machiavellianism and type A personality and ethical orientation [Electronic version]. Journal of Business Ethics, 15, 1209-1219.

Sari, D. R., \& Arruum, D. (2006). Stres dan koping perawat kepribadian tipe A dan kepribadian tipe B di ruang rawat inap RSU Dr. Pirngadi Medan [Electronic version]. Jurnal Keperawatan Rufaidah Sumatera Utara, 2 (1), 9-17.

Sims, R. R. (2002). Managing Organizational Behavior. Connecticut: Greenwood Publishing Group.

Smitts, E. (2010). Balancing a type A personality in the work place. Diambil 30 Desember 2012, dari http://richornothing.blogspot.com/2010/08/balancing-typepersonality-in-work.html

Steel, R. P., Griffeth, R. W., \& Hom, P. W. (2002). Practical retention policy for the practical manager [Electronic version]. Academy of Management Executive, 16, 149-162.

Stone, R. J. (1998). Human Resources Management (3rd ed.). Australia: John Wiley \& Sons Australia, Ltd.

Suhendro, P. A. (2008). Tingginya "Turnover" Karyawan di Indonesia. Diambil 13 November 2012, dari http://purjono.wordpress.com/2008/01 /15/tingginyaturnoverkaryawan-di-indonesia/

Sulasmi, N. (2012). Janjimu Janji Palsu: Karyawan Hari Ini. Diambil 23 Desember 2012, dari http://sulasmin.blogspot.com/

Sutanto, E. M., \& Djohan, L. (2006). Pengaruh persepsi akan dimensi desain organisasi dan tipe kepribadian terhadap tingkat stres karyawan PT. Internasional Deta Alfa Mandiri [Electronic version]. Jurnal Manajemen dan Kewirausahaan, 8, 25-39.

Suwandi \& Indriantoro, N. (1999). Model turnover Pasewark dan Strawser: studi empiris pada lingkungan akuntan publik. Jurnal Riset Akuntansi Indonesia. 2 (2), 173-195.

Turnley, W. H., \& Feldman, D. C. (1998). Psychological contract breach during corporate restructuring [Electronic version]. Human Resource Management, 37 (1), 71-83.

Witasari, L. (2009). Analisis pengaruh kepuasan kerja dan komitmen organisasional terhadap turnover intentions (studi empiris pada Novotel Semarang). Tesis yang tidak diterbitkan, Universitas Diponegoro.

You, M., \& Shim, H. (2012). The effect of psychological contract 


\section{INTENSI TURNOVER KARYAWAN BANK}

violation on employees' EVLN responses:the moderating effect of collectivism [Electronic version]. National Research Foundation of Korea Grant.

Zottoli. (2003). Understanding the process through which breaches of the psychological contract influence feelings of psychological contract violation. Disertasi yang tidak diterbitkan, Ohio State University. 